\begin{tabular}{c} 
International Journal of Scientific World, $5(1)(2017) 80-86$ \\
International Journal of Scientific World \\
SPC \\
Website: $\begin{array}{c}\text { ww. sciencepubco.com/index.php/IJSW } \\
\text { doi: } 10.14419 / \text { ijsw. } v 5 i 1.5275 \\
\text { Research paper }\end{array}$ \\
\hline
\end{tabular}

\title{
Predicting the mental health outcomes for Ebola first responders
}

\author{
Adam Kirby *, Merissa Hawkins, Randy Black, J. Eric Dietz \\ Purdue University, USA \\ *Corresponding author E-mail: kirbyphd@gmail.com
}

\begin{abstract}
Purpose: The 2014 Ebola epidemic resulted in 26,683 cases and 11,022 deaths by May 6th, 2015. With first responders deploying from the United States to assist with the many challenges being faced in the field, they encountered a new set of traumatic events and situations that undoubtedly put them at risk for developing a mental disorder. Organizations must be prepared to provide mental health services for their employees and volunteers once they return.

Approach: The authors questioned the potential prevalence of PTSD, ASD, and depression among returning first responders and which therapy method would be the most effective in terms of an individual's recovered or improved condition. This was done through the use of AnyLogic ${ }^{\circledR}$ 7.0. An agent-based method to model the stress levels a first responder may experience while dealing with Ebola was used, where all responders begin in the healthy state and can develop mental health disorders. The therapy options tested were Cognitive Processing Therapy, Prolonged Exposure, and Group Based Exposure Therapy.

Results: GBET for PTSD patients provided the most positive results in terms of condition recovery and improvement.

Conclusion: The results showed evidence that the type of therapy used can drastically affect the individual's mental health outcome.
\end{abstract}

Keywords: Ebola; First Responders; Mental Health; Anylogic; Modeling.

\section{Introduction}

This article reviews the prevalence and predictors of posttraumatic stress disorder (PTSD) and depression in first responders, in addition to utilizing AnyLogic ${ }^{\circledR} 7.0$ to (a) predict potential prevalence rates of these mental health responses in first responders attending to the 2014 Ebola crisis and (b) predict the most effective form of PTSD/depression therapy for those who begin to experience symptoms from trauma exposure. With first responders continuously exposed to trauma, life-treating situations, stress, and frustration more often than in comparison to the general population, it has been supported by a variety of studies and the US Department of Health and Human Services - Center for Mental Health Services [1] that first-responder groups experience a higher prevalence rate of PTSD and depression. According to these same organizations, 'first responders' is a broad term that encompasses several groups, including: medical personnel, paramedics, rescue disaster workers, emergency logisticians, firefighters, police officers, and military personnel. The nature of these situations typically requires these professionals to respond to a crisis first and remain present until general order is returned. They work with survivors, the injured and dead, and families of victims for extended periods of time, allowing for multiple potential traumatic exposures. An author review of the literature indicates that the mental health of first responders involved in larger traumatic crises is less often studied than the victims of the same crisis. However, more recent events like the Boston Marathon Bombing and terrorist attacks of 9/11/2001 have resulted in several studies supporting that the most frequent trauma-related disorder among first responders is PTSD [2] [3]. Studies also support that repeated exposure frequency [4] and previous exposures to traumatic events [2] are associated with increased risk of PTSD. Other researchers primarily focus on specific first-responder groups, such as paramedics [5], police officers [6], firefighters [7], and military personnel [8].

\section{Prevalence of PTSD and depression}

Specific prevalence rates of PTSD in first responders varied by study and first-responder group. Large-scale studies such as the one conducted by Perrin et al. [9], included 28,962 rescue and recovery workers working at the World Trade Center site on $9 / 11 / 2001$. Their overall prevalence rate for PTSD was $12.4 \%$, with values between $6.2 \%$ to $21.1 \%$ reported depending on professional role. Though not as large, a study conducted by Fullerton et al. [2] supports another research and found that first responders on 9/11/2001 not only had higher prevalence rates of PTSD (16.7\%) at 13 months after the event, but also depression (21.7\%). In a 2007 study published in Military Medicine, it was found that of 102 military healthcare providers who just returned from a recent deployment to Iraq or Afghanistan, 9\% met the criteria for PTSD and 5\% met the criteria for depression [8]. This study reviews individuals that not only are healthcare providers, but have had some training and preparation for potential traumatic events prior to the traumatic event and then exposure to it over an extended period of time.

In comparison to the national prevalence rate for PTSD (4\%) and depression $(10 \%)$ in the general population, first responders experience an overall prevalence rate of $8-26 \%$ for PTSD and 12.6$22 \%$ for depression [3] [2]. Several studies are reviewed in Table 1. 
Table 1: PTSD, Depression, and Other Case Studies

\begin{tabular}{|c|c|c|c|c|c|}
\hline & & & Prevalence & & \\
\hline $\begin{array}{l}\text { Stud } \\
\mathrm{y}\end{array}$ & Sample & Event & PTSD & $\begin{array}{l}\text { Depres- } \\
\text { sion }\end{array}$ & Other \\
\hline [2] & $\begin{array}{l}\text { Disaster } \\
\text { Workers }\end{array}$ & $9 / 11 / 2001$ & $16.7 \%$ & $21.7 \%$ & $\begin{array}{l}25.6 \\
\% \\
\text { (ASD } \\
\text { ) }\end{array}$ \\
\hline [9] & $\begin{array}{l}\text { Disaster } \\
\text { Workers }\end{array}$ & $9 / 11 / 2001$ & $12.4 \%$ & & \\
\hline [10] & $\begin{array}{l}\text { Police } \\
\text { Officers }\end{array}$ & $9 / 11 / 2001$ & $15.4 \%$ & & \\
\hline [8] & $\begin{array}{l}\text { Military } \\
\text { Health Care } \\
\text { Personnel }\end{array}$ & $\begin{array}{l}\text { Iraq or } \\
\text { Afghani- } \\
\text { stan De- } \\
\text { ployment }\end{array}$ & $9 \%$ & $5 \%$ & \\
\hline [11] & $\begin{array}{l}\text { Emergency } \\
\text { Room } \\
\text { Profession- } \\
\text { als }\end{array}$ & $\begin{array}{l}\text { No specif- } \\
\text { ic event }\end{array}$ & $\begin{array}{l}12 \% \text { (for- } \\
\text { mal) } \\
20 \% \text { (symp- } \\
\text { tomatic) }\end{array}$ & & \\
\hline [12] & $\begin{array}{l}\text { Medical } \\
\text { Emergency } \\
\text { Personnel }\end{array}$ & $\begin{array}{l}\text { No specif- } \\
\text { ic event }\end{array}$ & $\begin{array}{l}21.4 \% \\
\text { (symptomat- } \\
\text { ic) }\end{array}$ & & \\
\hline [13] & $\begin{array}{l}\text { Ambulance } \\
\text { Service } \\
\text { Workers }\end{array}$ & $\begin{array}{l}\text { No specif- } \\
\text { ic event }\end{array}$ & $21 \%$ & & \\
\hline [14] & Firefighters & $\begin{array}{l}\text { No specif- } \\
\text { ic event }\end{array}$ & $8 \%$ & & \\
\hline
\end{tabular}

\section{PTSD diagnosis}

According to the American Psychological Association Encyclopedia of Psychology [15], PTSD is defined as “... an anxiety problem that develops in some people after extremely traumatic events, such as combat, crime, an accident, or natural disaster. People with PTSD may re-live the event via intrusive memories, flashbacks and nightmares; avoid anything that reminds them of the trauma; and have anxious feelings they didn't have before that are so intense their lives are disrupted..." The Diagnostic and Statistical Manual of Mental Disorders [15] outlines the 20 symptoms associated with PTSD. These 20 symptoms have been modified and structured into a self-report measure and checklist, referred to as the PCL. A mental health professional will ideally spend a significant amount of time with an individual suffering from a potential mental health disorder and evaluate the patient's responses in regards to the symptoms listed. The PCL is reviewed and interpreted by a professional and given a score based on the individual's answers, somewhere between 0 and 80 points. A score of 38 or higher is currently being supported by the US Department of Veterans Affairs - National Center for PTSD [15] as meeting provisional screening criteria.

Traumatic events often associated with PTSD include terrorist attacks, natural disasters, violence, motor vehicle accidents, and war [1]. Exposure to traumatic events can negatively affect the first responder's ability to attend to victims and patients and increase the risk for developing PTSD [16]. According to the CDC [17], a crisis that extends for a prolonged amount of time places potential additional burden upon first responders (e.g., current 2014 Ebola crisis). With affected regions unable to control the disease within a timely manner, the outbreak now has become an epidemic. Serious progression has been made. However, as the number of new Ebola cases has reached a new low weekly totals and average number of new cases is steadily decreasing [17].

\section{Therapy options}

Therapy for stress disorders and depression varies depending on individual factors and disorder severity [18]. PTSD symptoms among first responders will likely interfere with their work and family relationships if left unadressed [13]. As with any disorder, a medical professional will ideally match individuals with therapies, they believe will be the most effective and result in a recovered and/or improved condition. Due to the very limited studies involving civilian first responders (e.g. police officers, firefighters, EMTs), results of veteran and military personnel therapy outcomes will be reviewed to provide insight on effective options. Therapies such as: prolonged-exposure therapy, cognitive processing therapy, eye-movement desensitization and reprocessing, group-based exposure therapy, and medications have all been recognized as effective methods to reduce symptoms of PTSD and depression [18]. However, prolonged-exposure (PE) therapy, cognitive processing therapy (CPT), and group-based exposure therapy (GBET) have been particularly successful in veteran and military populations [19] [20] [21]. See Table 2 and 3.

\begin{tabular}{|c|c|c|c|c|c|}
\hline \multicolumn{2}{|c|}{ Therapy } & \multicolumn{4}{|c|}{ Descriptive Summary } \\
\hline $\begin{array}{l}\text { Cognitive } \\
\text { Processing } \\
\text { Therapy } \\
\text { (CPT) }\end{array}$ & $\begin{array}{l}\text { A } \\
\text { vi } \\
\text { er } \\
\text { ar } \\
\text { in } \\
\text { de } \\
\text { at } \\
\text { T } \\
\text { g } \\
\text { fr } \\
\text { tr } \\
\text { th } \\
\text { tr } \\
\text { pr }\end{array}$ & \multicolumn{4}{|c|}{$\begin{array}{l}\text { A form of cognitive behavioral therapy that helps indi- } \\
\text { viduals understand the relationship between thoughts, } \\
\text { emotions, and behaviors, learn new patterns of thinking, } \\
\text { and practice new positive behaviors. It involves correct- } \\
\text { ing negative thought patterns so that memories of trauma } \\
\text { don't interfere with daily life. It may also include writing } \\
\text { about one's traumatic experience. } \\
\text { This therapy helps people reduce fear and anxiety trig- } \\
\text { gered by reminders of the trauma. This is done by con- } \\
\text { fronting (or being exposed to) trauma reminders in a safe } \\
\text { treatment environment until they are less troubling. In } \\
\text { this way, individuals can stop avoiding and reacting to } \\
\text { trauma reminders and live their lives more fully in the } \\
\text { present with greater freedom from the past. }\end{array}$} \\
\hline \multicolumn{2}{|c|}{$\begin{array}{l}\text { Prolonged } \\
\text { Exposure } \\
\text { (PE) Therapy }\end{array}$} & \multicolumn{4}{|c|}{$\begin{array}{l}\text { Similar to PE, GBET is an intensive group treatment that } \\
\text { targets PTSD symptoms through repeated imaginal and } \\
\text { in vivo exposure [21]. }\end{array}$} \\
\hline \multicolumn{6}{|c|}{ Table 3: PTSD Therapies in Veterans } \\
\hline \multicolumn{6}{|c|}{ PTSD Status } \\
\hline $\begin{array}{l}\text { Stud } \\
\mathrm{y}\end{array}$ & Therapy & $\begin{array}{l}\text { Recov- } \\
\text { ered }\end{array}$ & $\begin{array}{l}\text { Im- } \\
\text { proved }\end{array}$ & $\begin{array}{l}\text { Un- } \\
\text { changed }\end{array}$ & $\begin{array}{l}\text { Deteriorat- } \\
\text { ed }\end{array}$ \\
\hline [19] & CPT & $16.3 \%$ & $41.3 \%$ & $31.7 \%$ & $10.6 \%$ \\
\hline [22] & CPT & - & $50 \%$ & $50 \%$ & - \\
\hline$[20]$ & $\begin{array}{l}\text { PE } \\
\text { GBET \& }\end{array}$ & $50 \%$ & $30 \%$ & $20 \%$ & - \\
\hline [23] & $\begin{array}{l}\text { PE (Com- } \\
\text { bined) }\end{array}$ & $88 \%$ & $12 \%$ & - & - \\
\hline [21] & GBET & $70 \%$ & $30 \%$ & - & - \\
\hline [24] & GBET & & $81 \%$ & $19 \%$ & - \\
\hline [19] & $\begin{array}{l}\text { Wait-list, } \\
\text { No therapy }\end{array}$ & & $30 \%$ & $53 \%$ & $17 \%$ \\
\hline
\end{tabular}

\section{Ebola and AnyLogic ${ }^{\circledR}$}

The depleted West African health care systems, high levels of poverty, mistrust of hospitals and their staff, and low levels of education are requiring a large amount of international personnel and funds to respond. As of May 6th, 2015 there have been 26,683 (14,951 laboratory confirmed) cases of Ebola and 11,022 deaths, with a case-fatality rate between $41.3 \%$ and $73.7 \%$. However, death rates are estimated to be upwards of $60-70 \%$ [17]. The progression and international response of the Ebola crisis is unprecedented and will serve as a serious learning experience for public health and homeland security professionals

Simulation models have become particularly relevant and useful in analyzing public health emergencies. With Ebola projected to continue spreading throughout Africa and future outbreaks potentially transferring to other areas of the globe due to frequent international travel, understanding how stress disorders will influence the already insufficient first-responder force is of high importance. An AnyLogic 7 model will be presented showing potential outcomes of PTSD based on several variables.

As Ebola is a unique crisis, the trauma and situations encountered by first responders in an international setting are going to create additional cases of PTSD with triggers and memories that vary from previous events and epidemics. It will be crucial for organizations responding to the Ebola crisis to be knowledgeable and prepared to provide mental health services to their returning work- 
ers and volunteers. In this study, the authors question which of several therapy methods for returning Ebola workers will be most successful in improving or fully recovering individuals with PTSD, ASD, or Depression symptoms. Studies from veteran populations were used due to (a) the greater availability of reliable studies in this population, and (b) military personnel are considered a first responder.

\section{Methods}

AnyLogic 7 is a computer modeling program developed by The AnyLogic Company, formerly XJ Technologies. It is a Java-based simulation program that uses the Monte Carlo simulation method. This means it relies on random sampling to achieve its numeric results. The modeling method used for this research will be agentbased modeling. It helps simulate complex interactions between humans, deals with people in a limited amount of space, allows for heterogeneous populations, and allows the agents in the environment to execute complex behavior [25]. All of these characteristics are very important when modeling the stress level of responders to such an event. The disease, the responders, and the victims can all be treated as agents, each possessing their own set of unique characteristics which can change based on the environment or other agents around them.

Agent-based modeling is quickly becoming the most popular modeling method used for research. The agent-based approach provides very detailed simulation at both high and low level abstraction. A single model can deal with millions of different agents at once. However, such complex models require a very powerful computer. Most personal computers produced currently can handle some level of agent-based modeling. Agent-based models are usually used in one of four areas of research: flows, markets, organizations, or diffusion. According to Borschev, Karpov, and Kharitonov, the authors of the article claim that AnyLogic is one of the best pieces of simulation software in the world for dealing with agents [26]. The case of stress among responders is an example of diffusion, which is the spread of something based on factors that cause it.

Agent-based modeling is a great method to use when modeling responders dealing with casualties [27]. When responders are unable to keep up with the demands of the disaster, emergent behavior happens. Agent-based modeling allows for those possible outcomes to be analyzed prior to occurring in the real world.

Though agent-based modeling provides the best logic for modeling human behavior, accurately doing so can be very difficult. The predictions that the model makes are based upon data that must be collected in order to correctly model the behavior of the agents may have. Different factors such as size, age, level of understanding of the environment, gender, previous experience, or anything else that could categorize a person can all be important factors that may influence one agent's actions but not another's. The model will never be completely accurate because agents within a model have a predefined set of actions that they can take. In the real world, those agents have free will to execute actions that may be left out of the model [28].

One difficult part of modeling a stressful environment for responders in a multi-day simulation is shift scheduling. Shifts can be varied to find the optimal schedule for both the responders and the victims [29]. It is not realistic to think that responders will be able to work extremely long days in such an environment. Doing so would likely be a factor that would greatly impact their stress level. Using AnyLogic in conjunction with previous research, this study hopes to set forth an optimal strategy for dealing with responders in high-stress environments and see what steps can be taken to avoid stress wherever possible while still providing adequate service to victims.

The model's major portion of logic exists in the Responder agent. The agent contains a statechart that models the stress levels a first responder may experience while dealing with an Ebola (see Figure 1), specifically depression, ASD, and PTSD. All responders begin in the Healthy state. They can move from Healthy to Depression, ASD, or PTSD. The prevalence rates of the three conditions are taken directly from the study conducted by Fullerton et al. [2]. The study examined responders to the terrorist attacks on September 11, 2001 on the World Trade Center 13 months after the disaster. Their mental health conditions could have been developed at any given time over those 13 months. The model used in this research allows for that by using a triangular distribution for developing a mental health condition with zero months being least likely and thirteen months being most likely. Any responder who is not depressed moves to the StayHealthy state, indicating that his or her state of health has remained healthy.

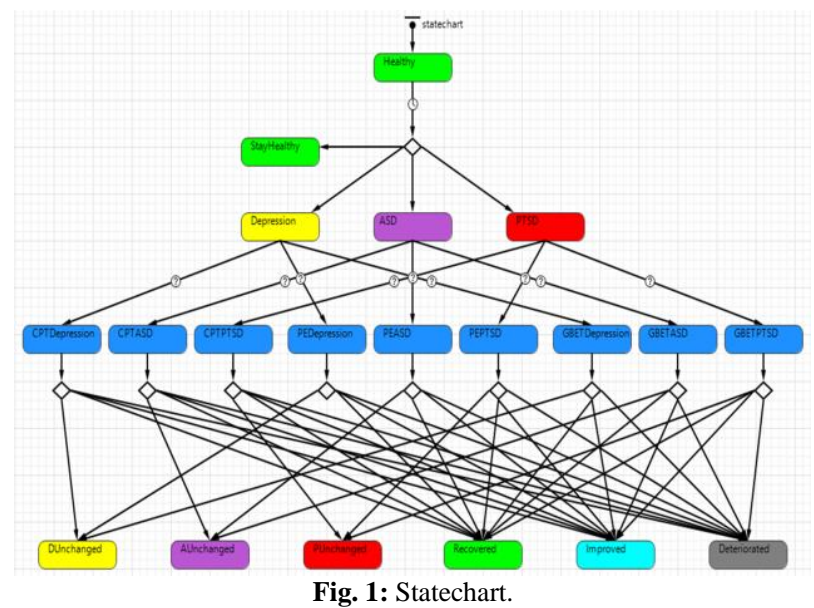

AnyLogic uses an object called a parameter to define a value that can be referenced by the statechart (see Figure 2). The branch of the statechart between the four possible states after Healthy uses three parameters. These parameters indicate the probabilities for each of the three mental health conditions. The probabilities used are $21.7 \%$ depression, $25.6 \%$ ASD, and $16.7 \%$ PTSD. Any agent that does not fall into one of these categories is assumed to remain healthy.

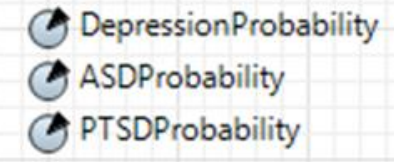

Fig. 2: Probabilities.

The model allows for the agents to go through one of three different therapy techniques for treatment of their mental health conditions. These three techniques are cognitive processing therapy $(\mathrm{CPT})$, prolonged exposure therapy (PE), and group-based exposure therapy (GBET). They are represented by the blue states under the three mental health conditions in the statechart. Each of these therapy techniques can have one of four different outcomes for the agent. The possible outcomes are that the agent's mental health recovered, improved, deteriorated, or remained unchanged. They are represented by the differently colored states below the therapy technique states. Depression, ASD, and PTSD unchanged states have their own respective outcomes in order to accurately show how many agents retained those mental health disorders. The outcomes for each of the therapy techniques all rely on different probabilities, and those probabilities vary depending on which of the therapy techniques is used. These outcomes are defined using nine additional parameters (see Figure 3). The outcomes for CPT were taken from the study of veterans conducted by Monson, Schnurr, Resick, Friedman, et al. [19]. The study concluded that the outcomes were identical in all forms of mental health disorders that they examined. In the study, $16.3 \%$ of veterans recovered, $41.3 \%$ Improved, and $10.6 \%$ deteriorated during a 10 -week treatment process. The remaining $31.7 \%$ for those who remained unchanged is calculated automatically by AnyLogic by taking $100 \%$ minus the three aforementioned. The outcomes for PE were taken 
from the study conducted by Rauch, Defever, Favorite, Duroe, et al. [20]. In the study, 50\% recovered, 30\% improved, and $0 \%$ deteriorated during a 23 -month treatment process. The remaining $20 \%$ is calculated by AnyLogic for those who remained unchanged. The outcomes for GBET were taken from the study conducted by Sutherland, Mott, Lanier, Williams, et al. [21]. In the study, $70 \%$ recovered, $30 \%$ improved, and $0 \%$ deteriorated during a 12 -week treatment process.

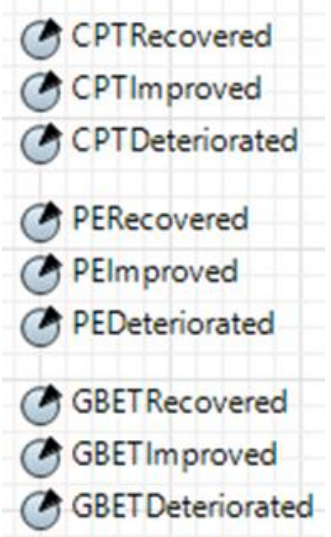

Fig. 3: Outcomes.

The second portion of the model logic is the Main agent. The main agent acts as the environment that the responder agents exist within. It also contains two parameters that represent the total population and the treatment type that is selected by the user (see Figure 4). The total population used for gathering results was set to 3000 responders for this study in order to create a large sample size.

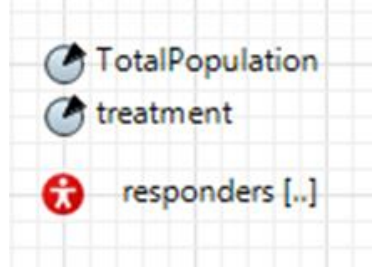

Fig. 4: Main Parameters.

In addition to the parameters, the Main agent also includes two charts for recording results for each simulation run. The first is a bar chart, and the second is a time stack chart. Both charts show the same data, which is how many agents are in each state at the current time (see Figure 5). Each chart shows seven different conditions that an agent can be in at any given time. Each condition is made up of certain states added together. Healthy represents any agent that has not yet had time to develop a mental health disorder, remained healthy, or is recovered. ASD represents any agent that has developed ASD and any agent that has received treatment but remained unchanged in their ASD state. PTSD represents any agent that has developed PTSD and any agent that has received treatment but remained unchanged in their PTSD state. Depression represents any agent that has developed depression and any agent that has received treatment but remained unchanged in their depression state. Improved represents any agent that improved from treatment. Deteriorated represents any agent that deteriorated from treatment. In Treatment represents any agent currently undergoing any one of the three types of treatment.

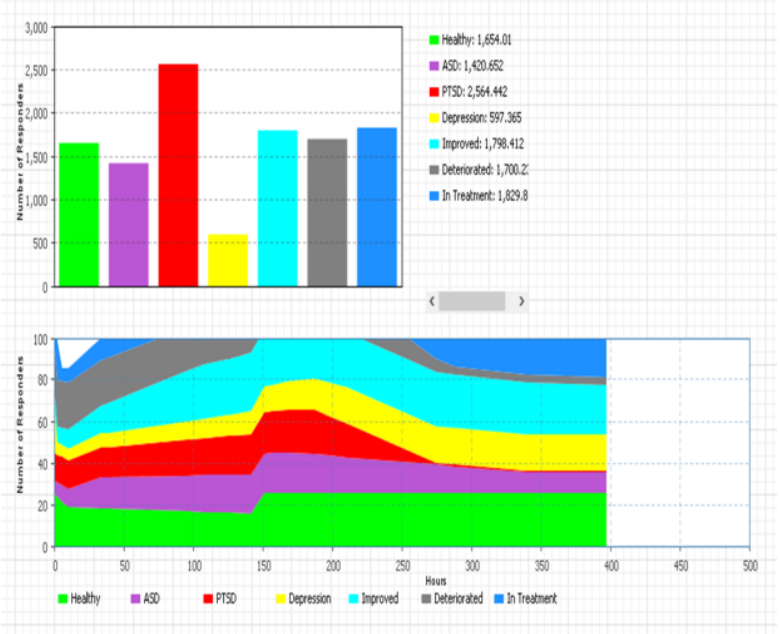

Fig. 5: Main Charts.

When the model is launched, the user is prompted with the Simulation start screen (see Figure 6). The user can choose between four different treatment types. By default, the treatment type is set to none. Running the model with this input will assume no treatment type is used. However, the user can select any of the other three treatment types and examine results which will be based upon the success and failure rates of each different treatment type. Once a treatment type is selected, the model is started by pressing the Run the model button.

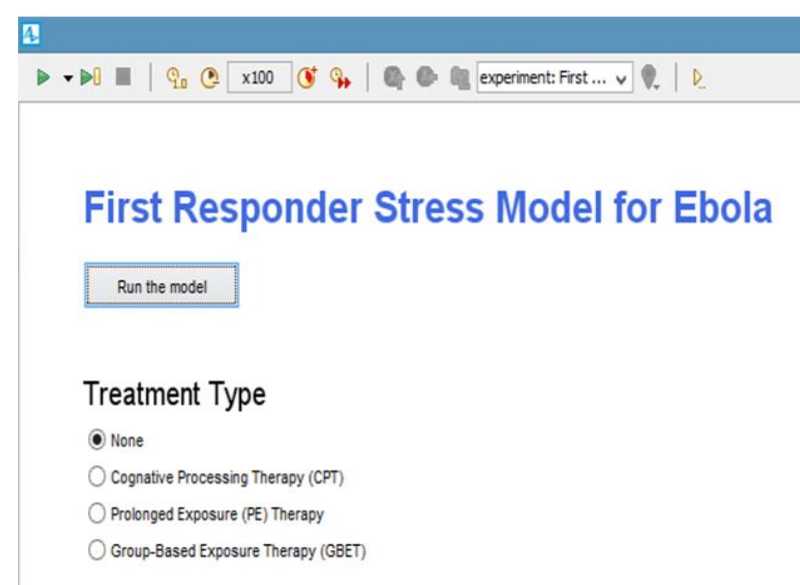

Fig. 6: Simulation Screen

The Main agent is then shown on the screen (see Figure 7). The environment containing the 3000 agents being simulated can be seen at the top. The two charts appear underneath the environment to display the results. The time units used in the model are hours. The time and date can be seen at the bottom of the screen. Since agents can take up to thirteen months to develop a mental health disorder and another twenty-three months to receive PE treatment, the model simulates a three-year period from January 1, 2015 at 12:00 AM through January 1, 2018 at 12:00 AM. 


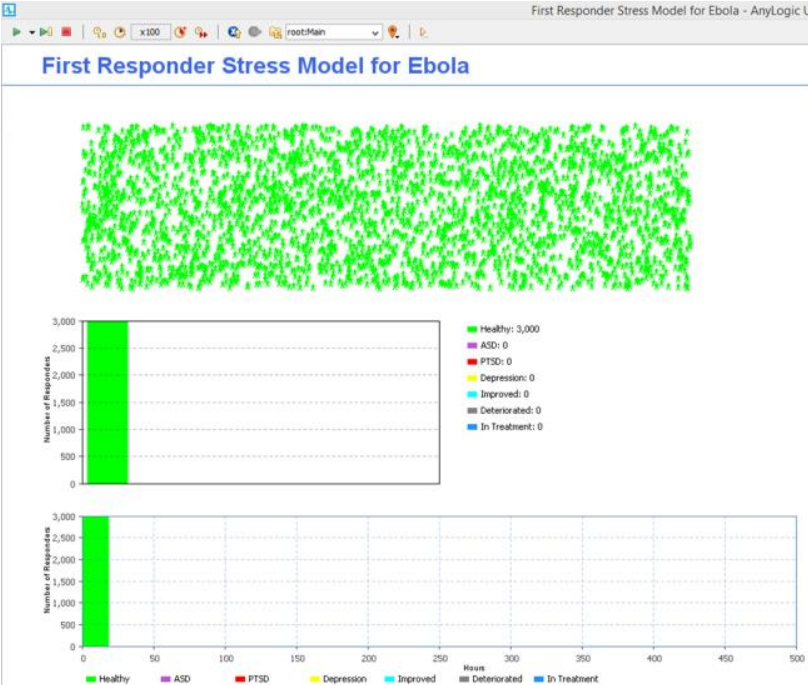

Fig. 7: Simulation: Main

When a simulation is finished, the results are displayed next to the bar chart (see Figure 8). The colors of the agents in the environment correspond to the colors of the bars they match in the charts.
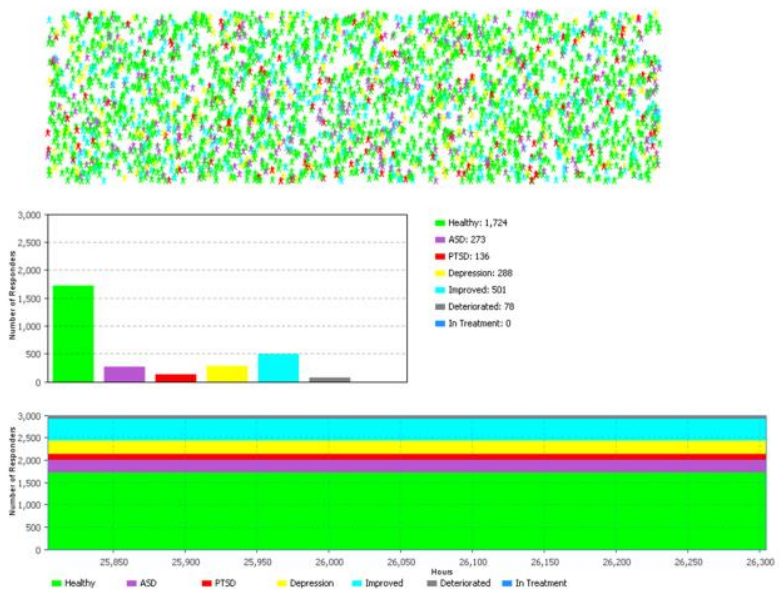

Fig. 8: Simulation Results.

\section{Results}

Results were gathered from the model by running ten simulations of each of the four user inputs for treatment types. The results show how each of the three types of therapy can improve the mental health of the 3000 responders being simulated by the model. The results of the 40 simulation runs can be seen in Tables 4-7.

Table 4: No Treatment Simulation Results

\begin{tabular}{llllllllllll} 
No & $\mathrm{R}$ & $\mathrm{R}$ & $\mathrm{R}$ & $\mathrm{R}$ & $\mathrm{R}$ & $\mathrm{R}$ & $\mathrm{R}$ & $\mathrm{R}$ & $\mathrm{R}$ & $\mathrm{Ru}$ & $\mathrm{Av}$ \\
Treat & un & un & un & un & un & un & un & un & un & $\mathrm{n}$ & er- \\
ment & 1 & 2 & 3 & 4 & 5 & 6 & 7 & 8 & 9 & 10 & age \\
\hline Healt & 15 & 14 & 14 & 14 & 14 & 14 & 14 & 14 & 14 & 15 & 145 \\
hy & 13 & 26 & 51 & 47 & 07 & 83 & 59 & 44 & 11 & 21 & 6.2 \\
ASD & 55 & 62 & 60 & 62 & 58 & 59 & 58 & 60 & 61 & 58 & 597 \\
& 4 & 6 & 7 & 2 & 2 & 0 & 8 & 5 & 9 & 0 & .3 \\
PTSD & 29 & 29 & 29 & 29 & 33 & 28 & 28 & 29 & 31 & 27 & 296 \\
$\begin{array}{l}\text { De- } \\
\text { pres- }\end{array}$ & 3 & 0 & 9 & 7 & 1 & 9 & 6 & 2 & 6 & 2 & .5 \\
sion & 0 & 8 & 3 & 4 & 0 & 8 & 7 & 9 & 4 & 7 & 650 \\
Im- & 0 & 0 & 0 & 0 & 0 & 0 & 0 & 0 & 0 & 0 & 0 \\
prove & & & & & & & & & & &
\end{tabular}

\begin{tabular}{llllllllllll}
$\begin{array}{l}\mathrm{d} \\
\begin{array}{l}\text { Dete- } \\
\text { ri- }\end{array}\end{array}$ & 0 & 0 & 0 & 0 & 0 & 0 & 0 & 0 & 0 & 0 & 0 \\
orated & & & & & & & & & & & \\
Total & 30 & 30 & 30 & 30 & 30 & 30 & 30 & 30 & 30 & 30 & 300 \\
& 00 & 00 & 00 & 00 & 00 & 00 & 00 & 00 & 00 & 00 & 0 \\
\hline
\end{tabular}

Table 5: CPT Simulation Results

\begin{tabular}{|c|c|c|c|c|c|c|c|c|c|c|c|}
\hline CPT & $\begin{array}{l}\mathrm{R} \\
\mathrm{un} \\
1\end{array}$ & $\begin{array}{l}\mathrm{R} \\
\text { un } \\
2 \\
\end{array}$ & $\begin{array}{l}\mathrm{R} \\
\text { un } \\
3 \\
\end{array}$ & $\begin{array}{l}\mathrm{R} \\
\text { un } \\
4 \\
\end{array}$ & $\begin{array}{l}\mathrm{R} \\
\text { un } \\
5 \\
\end{array}$ & $\begin{array}{l}\text { R } \\
\text { un } \\
6 \\
\end{array}$ & $\begin{array}{l}\mathrm{R} \\
\text { un } \\
7 \\
\end{array}$ & $\begin{array}{l}\mathrm{R} \\
\text { un } \\
8 \\
\end{array}$ & $\begin{array}{l}\mathrm{R} \\
\text { un } \\
9 \\
\end{array}$ & $\begin{array}{l}\mathrm{Ru} \\
\mathrm{n} \\
10 \\
\end{array}$ & $\begin{array}{l}\text { Av } \\
\text { er- } \\
\text { age }\end{array}$ \\
\hline Heat- & 17 & 17 & 17 & 17 & 17 & 17 & 16 & 16 & 16 & 16 & 170 \\
\hline lhy & 50 & 02 & 31 & 31 & 26 & 35 & 47 & 70 & 81 & 98 & 7.1 \\
\hline ASD & $\begin{array}{l}25 \\
9\end{array}$ & $\begin{array}{l}25 \\
7\end{array}$ & $\begin{array}{l}25 \\
9\end{array}$ & $\begin{array}{l}25 \\
8\end{array}$ & $\begin{array}{l}28 \\
1\end{array}$ & $\begin{array}{l}28 \\
2\end{array}$ & $\begin{array}{l}28 \\
3\end{array}$ & $\begin{array}{l}27 \\
0\end{array}$ & $\begin{array}{l}25 \\
7\end{array}$ & $\begin{array}{l}25 \\
6\end{array}$ & $\begin{array}{c}266 \\
.2\end{array}$ \\
\hline PTS & 12 & 13 & 11 & 12 & 12 & 11 & 13 & 13 & 12 & 12 & 125 \\
\hline D & 4 & 1 & 9 & 0 & 9 & 8 & 1 & 2 & 7 & 0 & .1 \\
\hline $\begin{array}{l}\text { De- } \\
\text { pres- } \\
\text { sion }\end{array}$ & $\begin{array}{l}27 \\
3\end{array}$ & $\begin{array}{l}30 \\
4\end{array}$ & $\begin{array}{l}29 \\
5\end{array}$ & $\begin{array}{l}26 \\
3\end{array}$ & $\begin{array}{l}28 \\
0\end{array}$ & $\begin{array}{l}25 \\
0\end{array}$ & $\begin{array}{l}30 \\
2\end{array}$ & $\begin{array}{l}31 \\
2\end{array}$ & $\begin{array}{l}30 \\
9\end{array}$ & $\begin{array}{l}28 \\
7\end{array}$ & $\begin{array}{l}287 \\
.5\end{array}$ \\
\hline $\begin{array}{l}\text { Im- } \\
\text { prove }\end{array}$ & $\begin{array}{l}51 \\
6\end{array}$ & $\begin{array}{l}53 \\
5\end{array}$ & 51 & 54 & 50 & 52 & 55 & 53 & 53 & 55 & 533 \\
\hline $\begin{array}{l}\text { d } \\
\text { Dete- }\end{array}$ & 6 & 5 & 9 & 8 & 5 & 4 & 9 & 8 & 6 & 1 & .1 \\
\hline $\begin{array}{l}\text { ri- } \\
\text { orat- } \\
\text { ed }\end{array}$ & 78 & 71 & 77 & 80 & 79 & 91 & 78 & 78 & 90 & 88 & 81 \\
\hline Total & $\begin{array}{l}30 \\
00 \\
\end{array}$ & $\begin{array}{l}30 \\
00 \\
\end{array}$ & $\begin{array}{l}30 \\
00 \\
\end{array}$ & $\begin{array}{l}30 \\
00 \\
\end{array}$ & $\begin{array}{l}30 \\
00 \\
\end{array}$ & $\begin{array}{l}30 \\
00 \\
\end{array}$ & $\begin{array}{l}30 \\
00 \\
\end{array}$ & $\begin{array}{l}30 \\
00 \\
\end{array}$ & $\begin{array}{l}30 \\
00 \\
\end{array}$ & $\begin{array}{l}30 \\
00\end{array}$ & $\begin{array}{l}300 \\
0 \\
\end{array}$ \\
\hline
\end{tabular}

Table 6: PE Simulation Results

\begin{tabular}{llllllllllll}
\hline & $\mathrm{R}$ & $\mathrm{R}$ & $\mathrm{R}$ & $\mathrm{R}$ & $\mathrm{R}$ & $\mathrm{R}$ & $\mathrm{R}$ & $\mathrm{R}$ & $\mathrm{R}$ & $\mathrm{Ru}$ & $\begin{array}{l}\mathrm{Av} \\
\text { PE }\end{array}$ \\
& un & un & un & un & un & un & un & un & un & $\begin{array}{l}\mathrm{n} \\
\text { er }\end{array}$ \\
& 1 & 2 & 3 & 4 & 5 & 6 & 7 & 8 & 9 & 10 & age \\
\hline Heat- & 21 & 22 & 22 & 22 & 22 & 22 & 22 & 22 & 22 & 21 & 222 \\
lhy & 86 & 28 & 41 & 32 & 23 & 10 & 31 & 89 & 51 & 95 & 8.6 \\
ASD & 21 & 21 & 19 & 21 & 19 & 22 & 20 & 17 & 20 & 21 & 206 \\
PTS & 6 & 9 & 7 & 1 & 3 & 6 & 9 & 7 & 6 & 4 & .8 \\
D & 9 & 4 & 10 & 10 & 10 & 10 & 90 & 87 & 95 & 10 & 101 \\
De- & 25 & 21 & 23 & 21 & 23 & 23 & 22 & 19 & 22 & 24 & 226 \\
pres- & 5 & 6 & 1 & 7 & 2 & 0 & 5 & 7 & 5 & 1 & .9 \\
sion & & & & & & & & & & & \\
Im- & 22 & 23 & 22 & 23 & 25 & 22 & 24 & 25 & 22 & 24 & 236 \\
prove & 4 & 3 & 8 & 4 & 1 & 7 & 5 & 0 & 3 & 8 & .3 \\
d & & & & & & & & & & & \\
$\begin{array}{l}\text { Dete- } \\
\text { ri- }\end{array}$ & & & & & & & & & & & \\
orat- & 0 & 0 & 0 & 0 & 0 & 0 & 0 & 0 & 0 & 0 & 0 \\
ed & & & & & & & & & & & \\
Total & 30 & 30 & 30 & 30 & 30 & 30 & 30 & 30 & 30 & 30 & 300 \\
\hline
\end{tabular}

Table 7: GBET Simulation Results

\begin{tabular}{llllllllllll}
\hline GBE & R & R & R & R & R & R & R & R & R & $\begin{array}{l}\text { Ru } \\
\text { Tv }\end{array}$ & $\begin{array}{l}\text { Av } \\
\text { er- }\end{array}$ \\
& 1 & 2 & 3 & 4 & 5 & 6 & 7 & 8 & 9 & 10 & age \\
\hline Heat- & 25 & 25 & 25 & 25 & 25 & 25 & 25 & 25 & 25 & 25 & 254 \\
lhy & 51 & 60 & 27 & 37 & 14 & 37 & 58 & 49 & 26 & 49 & 0.8 \\
ASD & 12 & 12 & 13 & 12 & 14 & 11 & 11 & 11 & 13 & 13 & 126 \\
PTS & 2 & 5 & 6 & 1 & 3 & 9 & 5 & 6 & 6 & 0 & .3 \\
D & 54 & 61 & 70 & 61 & 67 & 58 & 67 & 47 & 51 & 53 & 58 \\
De- & 13 & 11 & 14 & 14 & 13 & 14 & 12 & 14 & 14 & 12 & 135 \\
pres- & 7 & 5 & 0 & 2 & 8 & 8 & 4 & 5 & 1 & 2 & .2 \\
sion & & & & & & & & & & & \\
Im- & 13 & 13 & 12 & 13 & 13 & 13 & 13 & 14 & 14 & 14 & 138 \\
prove & 6 & 9 & 7 & 9 & 8 & 8 & 6 & 3 & 6 & 6 & .8 \\
d & & & & & & & & & & & \\
$\begin{array}{l}\text { Dete- } \\
\text { ri- }\end{array}$ & & & & & & & & & & & \\
orat- & 0 & 0 & 0 & 0 & 0 & 0 & 0 & 0 & 0 & 0 & 0 \\
ed & & & & & & & & & & & \\
Total & 30 & 30 & 30 & 30 & 30 & 30 & 30 & 30 & 30 & 30 & 300 \\
\hline
\end{tabular}

The averages for number of healthy agents after receiving each kind of treatment are shown in Figure 9. Figure 10 shows the 
number of agents that were either recovered or showed improvement from treatment.

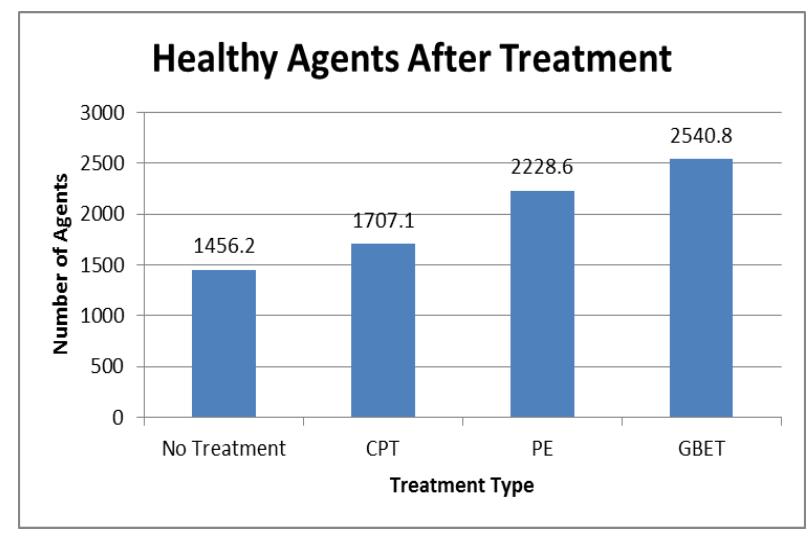

Fig. 9: Healthy Agents after Treatment.

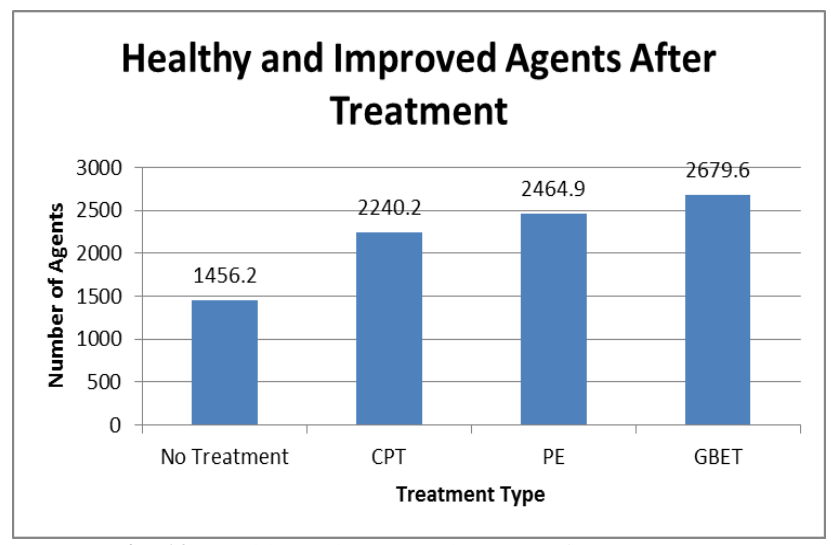

Fig. 10: Healthy and Improved Agents after Treatment.

Agents showed great improvement from each of the three treatment types. The number of healthy agents increased with each new therapy type simulated. This was to be expected because of the success rates reported in each of the studies used to populate the model parameters with data. The results show that different therapy techniques can be modeled using the model developed in this research. Further study can be performed to determine the outcomes of other therapy techniques or combining various therapy techniques. The combinations can be tested for results which can develop estimates for improvement from mental health disorders in responders in the real world. The estimates can be compared to real world data if those combinations of techniques are used.

\section{Conclusion}

Based off of the model results, Group Based Exposure Therapy is shown to be the most effective therapeutic approach to PTSD, ASD, and Depression improvement and recovery. As supported in previous studies, the group setting provides additional structure and support for participants [21]. This may also be supportive of lower drop-out rates of GBET therapy in comparison to other more individualistic forms such as PE and CPT [20].

With no current estimate of when the Ebola crisis will no longer need the assistance of international volunteers and workers, aid organizations must include and plan for the need of mental health care services and therapy. The trauma and situations encountered by first responders will create additional cases of PTSD with triggers unique to the Ebola epidemic. The authors recommend the consideration of required PCL completion by returning first responders and make GBET available to those interested in receiving mental health services. However, it would be recommended that further therapy options are processed through this model in order to confirm results. It would also be advised to use a variety of studies for statistical resource information beyond the ones listed in this article.

\section{References}

[1] Center for Mental Health Services. (2005). A guide to managing stress in crisis response professionals. US Department of Health and Human Services, 1-40.

[2] Fullerton, C. S., Ursano, R. J., \& Wang, L. (2004). Acute stress disorder, posttraumatic stress disorder, and depression in disaster or rescue workers. American Journal of Psychiatry, 16, 1370-1376. https://doi.org/10.1176/appi.ajp.161.8.1370.

[3] Kessler, R. C., Chin, W. T., Demler, O., Merikangas, K. R., \& Walters, E. E. (2005). Prevalence, severity, and comorbidity of 12 month DSM-IV disorders in the National Comorbidity Survey Replication. Archives of General Psychiatry, 62, 617-627. https://doi.org/10.1001/archpsyc.62.6.617.

[4] Eriksson, C. B., Vande Kemp, H., Gorsuch, R., Hoke, S., \& Foy, D. W. (2001). Trauma exposure and PTSD symptoms in international relief and development personnel. Journal of Traumatic Stress, 14, 205-212. https://doi.org/10.1023/A:1007804119319.

[5] Alexander, D. A., \& Klein, S. (2001). Ambulance personnel and critical incidents: Impact of accident and emergency work on mental health and emotional well-being. British Journal of Psychiatry, 178, 76-81. https://doi.org/10.1192/bjp.178.1.76.

[6] Pole, N. (2008). Predictors of PTSD in police officers: From childhood to retirement. In D. L. Delahanty (Ed.), the psychobiology of trauma and resilience across the lifespan (pp. 47-67). Landham, MD: Aronson

[7] Bryant, R. A., \& Harvey, A. G. (1996). Posttraumatic stress reactions in volunteer firefighters. Journal of Traumatic Stress, 9, 51-62. https://doi.org/10.1002/jts.2490090106.

[8] Greiger, T.A, Kolkow, T.T., Spira, J.L., Morse, J.S., (2007) Posttraumatic Stress Disorder and Depression in Health Care Providers Returning from Deployment to Iraq and Afghanistan. Military Medicine. 172, 451 https://doi.org/10.7205/MILMED.172.5.451.

[9] Perrin, M. A., Digrande, L., Wheeler, K., Thorpe, L., Farfel, M., \& Brackbill, R. (2007). Differences in PTSD prevalence and associated risk factors among World Trade Centre disaster rescue and recovery workers. American Journal of Psychiatry, 164, 1385-1394. https://doi.org/10.1176/appi.ajp.2007.06101645.

[10] Pietrzak, Schechter, Bromet, Katz, Reissman, Ozbay, Sharma, Crane, Harrison, Herbert, Levin, Luft, Moline, Stellman, Udasin, Landrigan, Southwick (2012) The burden of full and subsyndromal posttraumatic stress disorder among police involved in the World Trade Center rescue and recovery effort. Journal of Psychiatric Research 46(7), $835-842$ https://doi.org/10.1016/j.jpsychires.2012.03.011.

[11] Laposa, J.M \& Alden, L.E. (2003) Posttraumatic stress disorder in the emergency room: exploration of a cognitive model. Behaviour Research and Therapy. 41(1):49-65, ISSN 0005-7967 https://doi.org/10.1016/s0005-7967(01)00123-1.

[12] Ho, S., \& Lo, R. (2012). Dispositional Hope as a Protective Factor among Medical Emergency Professionals: A Preliminary Investigation. Traumatology, (17), 3-9.

[13] Clohessy, S., \& Ehlers, A. (1999). PTSD symptoms, response to intrusive memories and coping in ambulance service workers. British Journal of Clinical Psychology, (38), 251-265. https://doi.org/10.1348/014466599162836.

[14] Del Ben, K., Scotti, J., Chen, Y., Fortson, B., (2007) Prevalence of posttraumatic stress disorder symptoms in firefighters. Work \& Stress: An International Journal of Work, Health \& Organizations. 20. https://doi.org/10.1080/02678370600679512.

[15] American Psychiatric Association. (2013) Diagnostic and statistical manual of mental disorders, (5th ed.). Washington, DC: Author.

[16] Kleim, B., Westphal, M. (2011) Mental Health in First Responders: A Review and Recommendation for Prevention and Intervention Strategies. $\quad$ Traumatology. 17(4) 17-24 https://doi.org/10.1177/1534765611429079.

[17] CDC (2014). Ebola Virus Disease. Retrieved from http://www.cdc.gov/vhf/ebola/index.html, Dec. 2 Atlanta: Centers for Disease Control and Prevention.

[18] DeAngelis, T. (2008). PTSD treatments grow in evidence, effectiveness. Monitor on Psychology, 39, 40.

[19] Monson, C., Schnurr, P., Resick, P., Friedman, M., Young-Xu, Y., \& Stevens, S. (2006). Cognitive Processing Therapy For Veterans With Military-related Posttraumatic Stress Disorder. Journal of Consulting and Clinical Psychology, 74, 898-907. https://doi.org/10.1037/0022-006X.74.5.898. 
[20] Rauch, S., Defever, E., Favorite, T., Duroe, A., Garrity, C., Martis, B., \& Liberzon, I. (2009). Prolonged Exposure For PTSD In A Veterans Health Administration PTSD Clinic. Journal of Traumatic Stress, 22, 60-64. https://doi.org/10.1002/jts.20380.

[21] Sutherland, R., Mott, J., Lanier, S., Williams, W., Ready, D., \& Teng, E. (2012). A pilot study of a 12-week model of group-based exposure therapy for veterans with PTSD. Journal of Traumatic Stress, 25, 150-156. https://doi.org/10.1002/jts.21679.

[22] Alvarez, J., Mclean, C., Harris, A., Rosen, C., Ruzek, J., \& Kimerling, R. (2011). The comparative effectiveness of cognitive processing therapy for male veterans treated in a VHA posttraumatic stress disorder residential rehabilitation program. Journal of Consulting and Clinical Psychology, 79, 590-599. https://doi.org/10.1037/a0024466.

[23] Ready, D., Vega, E., Worley, V., \& Bradley, B. (2012). Combining Group-Based Exposure Therapy With Prolonged Exposure to Treat U.S. Vietnam Veterans With PTSD: A Case Study. Journal of Traumatic Stress, 25, 574-577. https://doi.org/10.1002/jts.21734.

[24] Ready, D., Thomas, K., Worley, V., Backscheider, A., Harvey, L. Baltzell, D., \& Rothbaum, B. (2008). A field test of group based exposure therapy with 102 veterans with war-related posttraumatic stress disorder. Journal of Traumatic Stress, 21, 150-157. https://doi.org/10.1002/jts.20326.

[25] Bonabeau, E. (2002). Agent-based modeling: Methods and techniques for simulating human systems. Proceedings of the National Academy of Sciences of the United States of America. Retrieved from http://www.pnas.org/content/99/suppl.3/7280.short\#sec-1, 4/24/2013. https://doi.org/10.1073/pnas.082080899.

[26] Borshchev, A., Karpov, Y., \& Kharitonov, V. (2001). From system dynamics and discrete event to practical agent based modeling: Reasons, techniques, tools. 6th International Conference on Parallel Computing Technologies. Retrieved from http://tinyurl.com/keq9bhp, 4/24/2013

[27] Shendarkar, A., \& Vasudevan, K. (2006). Crowd simulation for emergency response using BDI agent based on virtual reality. In L. F. Perrone, F. P. Wieland, J. Liu, B. G. Lawson, D. M. Nicol, and R. M. Fujimoto (Eds.), 2006 Winter Simulation Conference, (pp. 545553). Retrieved from http://www.informssim.org/wsc06papers/067.pdf. 4/24/2013. https://doi.org/10.1109/wsc.2006.323128

[28] Muhdi, R. A. (2006). Evacuation modeling: Development, characteristics, and limitations. Proceedings of the IEEE CEC, Vancouver, BC, Canada, (pp. 87-92). Retrieved from http://www.mech.utah.edu/ergo/pages/NORA/2006/8792\%20Muhdi,\%20Rani.pdf., 4/24/2013.

[29] Banerjee, D., Dasgupta, G., \& Desai, N. (2011). Simulation-based evaluation of dispatching. In S. Jain, R. Creasey, J. Himmelspach, K. White, and M. Fu (Eds.), 2011 Winter simulation conference, (pp. 779-791). https://doi.org/10.1109/WSC.2011.6147805. 